\title{
EDUKACJA WŁĄCZAJĄCA I INTEGRACYJNA. O POZORNEJ TOŻSAMOŚCI ZNACZEŃ
}

\author{
Aleksandra Antonik, ola.antonik@gmail.com \\ Uniwersytet im. Adama Mickiewicza \\ ul. Wieniawskiego 1, 61-712 Poznań
}

@) $\odot \Theta \Theta$

\section{STRESZCZENIE}

Aktualnym światowym standardem i celem reform w zakresie edukacji osób o specjalnych potrzebach, wyznaczanym przez międzynarodowe organizacje takie jak UNESCO, jest umożliwianie im korzystania z wysokiej jakości kształcenia w ramach szkół rejonowych. Celem artykułu jest naświetlenie podstawowych różnic pomiędzy edukacją włączającą a integracyjna, która często jest błędnie utożsamiana z tą pierwsza, pozostającą bliżej form segregacyjnych. Analiza przeprowadzona została w oparciu o akty prawne regulujące kształt - aspirującego do miana włączającego - polskiego systemu edukacyjnego.

Słowa kluczowe: edukacja włączająca, edukacja integracyjna, specjalne potrzeby edukacyjne.

Inlusive and integrated education. The apparent identity of meanings

\begin{abstract}
Nowadays many countries tend to change their educational systems to enable people with special educational needs learning in their local schools. Poland is among them, trying to make its system more inclusive. The aim of this article is to show a few main aspects of inclusion and integration, that are frequently treated as synonyms, however the second one is closer to the concept of segregation. Some Polish legal acts concerning education have been analyzed to identify it's affiliation, and emphasize the key differences between both systems.
\end{abstract}

Key words: inclusive education, integrated education, special educational needs.

\section{SŁOWO JAKO NARZĘDZIE KONSTRUOWANIA SPOŁECZNEJ RZECZYWISTOŚCI}

Edukacja włączająca stanowi skrajny biegun na osi zmian w sposobie traktowania przez społeczeństwo jednostek odbiegających od szeroko pojętej normy. Stosunek ten na przestrzeni wieków ewoluował od całkowitego wykluczenia i fizycznej eksterminacji osób z różnego rodzaju deficytami, poprzez ich segregację, a następnie integrację, aż po włączanie w normalne struktury życia społecznego ${ }^{1}$. Pomimo świadomości istnienia owych przemian w literaturze pedagogicznej wciąż panuje pewien chaos pojęciowy, co skutkuje brakiem jasno określonych różnic pomiędzy systemem integracyjnym i włączającym. Nieścisłości te z kolei mają swoje konsekwencje w sposobie realizowania praktyki edukacyjnej na poziomie organizacyjnym. Analizując postulowane przez Konwencję Praw Osób Niepełnosprawnych założenia w zestawieniu z ich praktyczną implikacją w oświatowych aktach prawnych zauważa się wyraźny dysonans. Efekty reform, już określane jako edukacja włączająca, wciąż pozostają poza zasięgiem jej definicji.

Budowanie społecznej rzeczywistości oparte jest na aktach komunikacji międzyludzkiej. Zjawiska społeczne kształtują się w zależności od tego, jak ludzie je nazywająi interpretują poprzez dobór słów. W świetle koncepcji konstruktywizmu komunikacyjnego prawo jest zbiorem definicji zjawisk nadanych rzeczywistości przez ludzi zamieszkujących dane państwo. Jest przy tym narzędziem służącym legitymizowaniu określonych praktyk społecznych². Przedstawiona w dalszej części artykułu analiza skupia się na warstwie definicyjnej rozporządzeń nadających kształt polskiemu systemowi kształcenia uczniów ze specjalnymi potrzebami edukacyjnymi, ze szczególnym uwzględnieniem osób z niepełnosprawnością

\footnotetext{
1 W. Dykcik, Wprowadzenie w przedmiot pedagogiki specjalnej jako nauki, [w:] W. Dykcik (red.) Pedagogika specjalna, Poznań 2006, s. 45-46.

2 M. Wendland, Konstruktywizm komunikacyjny, Poznań 2011, s. 21-22.

3 Rozporządzenie Ministra Edukacji Narodowej z dnia 30 kwietnia 2013 r. w sprawie zasad udzielania i organizacji pomocy psychologiczno-pedagogicznej w publicznych przedszkolach, szkołach i placówkach (Dz.U. z 2013 r., poz.532); Rozporządzenie Ministra Edukacji Narodowej z dnia 17 listopada 2010 r. w sprawie
} 
Pod uwagę zostaną wzięte niektóre elementy decydujące o przechyleniu go w stronę integracji lub segregacji. Choć skupienie się na sposobie formułowania ustępów i rodzaju używanych do tego określeń może wydać się działaniem powierzchownym, to w rzeczywistości jest dobrym narzędziem do demaskowania ideologicznego podłoża, na którym oparte jest prawo oświatowe, oraz sposobu myślenia o niepełnosprawności narzucanego przez ustawodawcę.

\section{WSPÓŁCZESNE STANDARDY KSZTAŁCENIA OSÓB O SPECJALNYCH POTRZEBACH EDUKACYJNYCH}

Temat kształcenia osób z niepełnosprawnościami jest współcześnie bardzo często obecny w publicznej debacie o kształcie nowoczesnego systemu edukacji. Jest to związane między innymi z faktem ratyfikowania przez Polskę w roku 2012 Konwencji Praw Osób Niepełnosprawnych. Ratyfikacja Konwencji była zobowiązaniem do sukcesywnego wdrażania w życie jej postanowień. Podstawowym elementem, na którym ukonstytuowane są wszystkie jej postulaty, jest zapewnienie osobom z niepełnosprawnością równego, nieskrępowanego dostępu do wszystkich sfer życia publicznego na zasadzie równości z innymi ludźmi. Artykuł 24. Konwencji poświęcony jest edukacji włączającej, zwanej również inkluzywna, która jest obecnie zarówno standardem, jak i celem reform oświatowych wielu krajów na świecie. Zgodnie z postulowaną przez UNESCO definicją, edukacja inkluzywna oznacza sytuację, w której szkoła ogólnodostępna jest przygotowana na przyjęcie i sprostanie potrzebom edukacyjnym każdego dziecka, bez względu na jego indywidualne zasoby rozwojowe, kulturowe czy społeczne ${ }^{5}$. Włączanie powinno obejmować przy tym wszystkich uczniów o specjalnych potrzebach edukacyjnych, do których zaliczane są zarówno osoby posiadające różnego typu zaburzenia organiczne, jak i osoby pochodzące z defaworyzowanych środowisk społecznych oraz osoby wybitne uzdolnioné6.

\section{INTEGRACJA, INKLUZJA - POZORNA TOŻSAMOŚĆ ZNACZENIOWA}

Termin „integracja” pochodzi zjęzyka łacińskiego (łac. integrare) i dosłownie oznacza tworzenie całości z częścī. Każda nauka szczegółowa definiuje ten termin nieco inaczej, podkreślając ważne dla siebie elementy rzeczywistości. W naukach pedagogicznych podstawą do definiowania integracji jest podejście socjologiczne - jest to więc scalanie, zbliżanie grup społecznych, wyrażające się w tworzeniu środowiska wielostronnego rozwoju, które pozwala na zaspokojenie indywidualnych potrzeb oraz umożliwia swoim członkom pełne uczestnictwo w różnych wymiarach życia społecznego. Wszystko to razem konstytuuje podstawę pojęciową integracyjnego systemu edukacji, który ma być środkiem do osiaggania integracji społecznej. W polskiej literaturze przedmiotu ${ }^{8}$ zazwyczaj przywołuje się definicję integracji opracowaną przez Aleksandra Hulka. Według niego integracja polega na „maksymalnym włączeniu dzieci i młodzieży z odchyleniami od normy do zwykłych szkół $\mathrm{i}$ innych placówek oświatowych, umożliwiających im - w miarę możliwości - wzrastanie w gronie zdrowych rówieśników. Jednostkom zaś przebywającym w zakładach opiekuńczych stara się zapewnić jak najczęstsze kontakty z zewnętrznym środowiskiem społecznym" ${ }^{\prime \prime}$.

Według definicji słownikowej termin „,inkluzja” oznacza stosunek zachodzący pomiędzy dwoma zbiorami, kiedy to jeden zawiera się $\mathrm{w}$ drugim $^{10}$. Na gruncie nauk społecznych termin ten jest bardzo podobny do pojęcia integracji, dlatego często oba pojęcia są ze sobą mylone lub stosowane wymiennie. Nieporozumienia w tym względzie mogą wynikać z samej definicji słowa „"integracja”, które ma znaczenie szerokie i teoretycznie może oznaczać również praktyki włączające. W pewnym sensie jest to najwyższy stopień integracji, nazywany przez niektórych autorów integracją całkowitą lub totalnąa ${ }^{11}$. Pomimo, iż różnica między tymi pojęciami jest teoretycznie niewielka, w praktyce jest bardzo znacząca i implikuje

warunków organizowania kształcenia, wychowania i opieki dla dzieci i młodzieży niepełnosprawnych oraz niedostosowanych społecznie w specjalnych przedszkolach, szkołach i oddziałach oraz ośrodkach (Dz.U. Nr 228, poz.1489); Rozporządzenie Ministra Edukacji Narodowej z dnia 17.11 .2010 r. w sprawie warunków organizowania kształcenia, wychowania i opieki dla dzieci i młodzieży niepełnosprawnych oraz niedostosowanych społecznie w przedszkolach, szkołach i oddziałach ogólnodostępnych lub integracyjnych wraz z późniejszymi zmianami (Dz. U. Nr 228, poz.1490 oraz Dz.U. z 2012 r., poz. 982 i Dz.U. z 2013 r., poz. 957 ).

4 Konwencja o prawach osób niepełnosprawnych, Dz.U. z 2012 r., poz. 1169.

5 UNESCO, Open file on inclusive education, Support materials for managers and administrators, Paris 2001, s. 20-21.

6 H. Krauze-Sikorska, Praca z dziećmi o specjalnych potrzebach edukacyjnych i jej implikacje dla ich rozwoju, [w:] H. Sowińnka (red.) Dziecko w szkolnej rzeczywistości. Założony a rzeczywisty obraz edukacji elementarnej, Poznań 2011, s. 483-486.

7 Integracja, w: Słownik Języka Polskiego PWN, http://sjp.pwn.pl/sjp/integracja;2561723.html, 25.11.2014.

8 Zob. D. Apanel, Teoria i praktyka ksztakcenia integracyjnego w Polsce w latach 1989-2012, Toruń 2014, s. 74; J.Lipińska-Lokś, Zmiany stosunków między dziécmi petnosprawnymi w dziécmi z niepetnosprawnościa w klasach integracyjnych, Zielona Góra 2011, s. 24.

9 A. Hulek, Integracyjny system kształcenia i wychowania, [w:] A.Hulek (red.), Pedagogika rewalidacyjna, Warszawa 1980, s. 492.

10 Inkluzja, w: Słownik Języka Polskiego PWN, Inkluzja http://sjp.pwn.pl/sjp/inkluzja;2466290.html, 25.11.2014.

11 J. Kossewska, Wspótczesne modele integracji szkolnej dzieci niepetnosprawnych, http://libproxy.up.krakow.pl/plikownia/pdf/kossewska_02.pdf, 28.12.2014. 
poważne konsekwencje. Brak trafnych i klarownych pojęć, jak zauważa Grzegorz Szumski, jest czynnikiem hamującym postęp danej dziedziny nauki przez zablokowanie możliwości kumulowania wiedzy na dany temat ${ }^{12}$.

Różnica pomiędzy integracją a inkluzją tkwi w samym punkcie wyjścia, jakim jest myślenie o tym, co mieści się w pojęciu normy. Fundamentalnym założeniem edukacji włączającej jest respektowanie odmienności i poszanowanie dla niej. Różnorodnośćniejest przy tym traktowana jako zjawisko negatywne, leczjako normalna cecha społeczeństw. Organizacja takiego systemu edukacji nie polega na tworzeniu specjalnej infrastruktury, lecz na reorganizacji powszechnego systemu szkolnictwa w taki sposób, aby był przygotowany na z góry założoną różnorodność potrzeb uczniów ${ }^{13}$.

W związku z pozorną tożsamością znaczeń zwolennikom inkluzji zarzuca się, że „ubierają stare praktyki w nowe szaty", co jest po części uzasadnione, biorąc pod uwagę zauważalny w środowisku pedagogicznym brak całkowitej zgodności co do rozłączności obu pojęć. Przyjmuje się, że oba omawiane systemy nie stoją wobec siebie w opozycji. Są to raczej różne stadia rozwoju systemu edukacji umiejscowionego na symbolicznym kontinuum segregacja-integracja-inkluzja, a różnice między nimi mają charakter jakościowy ${ }^{14}$. Różnica tkwi w dużej mierze w praktycznej realizacji. Elementy swoiste charakterystyczne dla każdego z pojęć zostaną omówione w dalszej części rozważań.

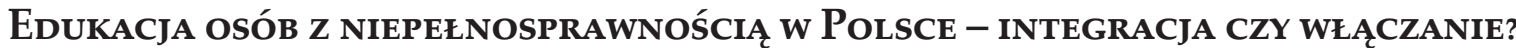

W ostatnich latach, w literaturze z zakresu pedagogiki specjalnej, terminy „edukacja włączająca” lub „edukacja inkluzywna" bardzo często są stosowane jako synonimy słowa "integracja” i używane wymiennie. W rzeczywistości zakres znaczeniowy tych dwóch pojęć różni się w znacznym stopniu. Bardzo niekorzystnym zjawiskiem jest przypisywanie polskiemu systemowi edukacji znamion inkluzywności, uzasadniając to teoretycznym brakiem barier $\mathrm{w}$ dostępie do szkolnictwa ogólnodostępnego przez osoby z niepełnosprawnościa. Wynika to prawdopodobnie z niezrozumienia istoty edukacji włączającej lub braku świadomości rozłączności obu pojęć. Biorąc pod uwagę wady, jakimi charakteryzuje się funkcjonujący system oświaty, określanie go mianem włączającego stwarza zagrożenie wadliwego ukonstytuowania się właściwej definicji edukacji włączającej, która dopiero rodzi się w społecznej świadomości Polaków. Przypisywaniejejniewłaściwych praktyk stosowanych w integracji budzi ogólną niechęć i ogranicza możliwości implementacji tego nowego, rewolucyjnego podejścia do kwestii edukacji.

Obecnie w Polsce funkcjonują równolegle dwa systemy edukacyjne - ogólnodostępny i specjalny, przy czym uczniowie z niepełnosprawnością mogą kształcić się w każdym typie szkoły. Taki system określany jest, według klasyfikacji Grzegorza Szumskiego, mianem „wspólnego nurtu” ${ }^{\prime 15}$. Brak administracyjnych przeszkód w dostępie do edukacji ogólnodostępnej nie jest jednak jednoznaczny z pełnym dostępem do niej. Zaporą jest w tym wypadku brak adekwatnego wsparcia pozwalającego niwelować skutki posiadanych dysfunkcji. Zmiana Rozporządzenia Ministra Edukacji Narodowej w sprawie zasad udzielania i organizacji pomocy psychologiczno-pedagogicznej w publicznych przedszkolach, szkołach i placówkach ${ }^{16}$ doprowadziła do rozszerzenia katalogu sytuacji kwalifikujących uczniów do otrzymywania specjalistycznej pomocy w przypadku wystąpienia u nich trudności w sprostaniu wymogom powszechnego systemu edukacji. Zmiana ta stanowi ważny krok w kierunku edukacji włączającej, choć wciąż funkcjonuje wiele barier uniemożliwiających jej petne urzeczywistnienie.

Pierwszym z analizowanych aspektów jest definicja specjalnych potrzeb edukacyjnych stosowana w rozporządzeniach Ministra Edukacji Narodowej. Zawierają one katalog sytuacji, których zaistnienie jest podstawą do zakwalifikowania ucznia jako posiadającego specjalne potrzeby edukacyjne. Lista ta obejmuje uczniów, których trudności edukacyjne wynikaja:

- $\quad$ z niepełnosprawności - kategoria ta obejmuje osoby niesłyszące, słabo słyszące, niewidome, słabo widzące, $\mathrm{z}$ niepełnosprawnością ruchową ( $\mathrm{w}$ tym $\mathrm{z}$ afazją), $\mathrm{z}$ upośledzeniem umysłowym, $\mathrm{z}$ autyzmem i zespołem Aspergera, z niepełnosprawnościami sprzężonymi;

- $\quad$ z niedostosowania społecznego;

- $\quad$ z zagrożenia niedostosowaniem społecznym ${ }^{17}$;

\footnotetext{
12 G. Szumski, Integracyjne kształcenie niepetnosprawnych. Sens i granice zmiany edukacyjnej, Warszawa 2009, s. 98-99.

13 J.W. Kugelmass, The inclusive school. Sustaining equity and standards, New York 2004, s. 3-4.

14 A. Czyż, Idea edukacji włączającej w opinii pedagogów, Kraków, 2013, s. 38.

15 Tamże, s. 173-174.

16 Rozporządzenie Ministra Edukacji Narodowej z dnia 30 kwietnia 2013 r., dz. cyt.

17 Rozporządzenie Ministra Edukacji Narodowej z dnia 17 listopada 2010 r., dz. cyt.
} 
- $\quad$ ze szczególnych uzdolnień;

- $\quad$ ze specyficznych trudności w uczeniu się;

- $\quad$ z zaburzeń komunikacji językowej;

- $\quad$ z choroby przewlekłej;

- $\quad$ z sytuacji kryzysowych lub traumatycznych;

- $\quad$ z niepowodzeń edukacyjnych;

- $\quad$ z zaniedbań środowiskowych związanych z sytuacją bytową ucznia i jego rodziny, sposobem spędzania czasu wolnego i kontaktami środowiskowymi;

- $\mathrm{z}$ trudności adaptacyjnych związanych z różnicami kulturowymi lub ze zmianą środowiska edukacyjnego, w tym z wcześniejszym kształceniem za granicą ${ }^{18}$.

Przytoczona lista jest długa i obejmuje wiele jednostek, w tym klinicznych, których diagnoza kwalifikuje dziecko jako posiadające specjalne potrzeby edukacyjne. Porównując to z sytuacją krajów mogących pochwalić się systemami edukacji uważanymi za bliskie urzeczywistnienia idei inkluzji, można zauważyć, że ich definicje są bardzo ogólne i nie wskazują żadnych konkretnych jednostek klinicznych jako przyczyny problemów. W Wielkiej Brytanii uczeń ze specjalnymi potrzebami edukacyjnymi to osoba która „doświadcza większych trudności szkolnych niż większość jego rówieśników i z którymi nie może sobie poradzić w 〉>normalnychく< warunkach. Mogą być one przez dziecko przezwyciężone pod warunkiem zapewnienia mu odpowiedniego wsparcia. Wsparcie to oznacza dodatkową pomoc lub jakiekolwiek interwencje, które wykraczają poza standardowe działania szkoły ogólnodostępnej"19. Tak szeroka definicja stwarza możliwość udzielania specjalistycznej pomocy psychologiczno-pedagogicznej każdemu uczniowi, bez konieczności sporządzania oficjalnej diagnozy.

Kolejnym rozważanym zagadnieniem jest znaczenie, jakie system nadaje pojęciu niepełnosprawności. W integracji precyzyjna diagnoza kliniczna jest bardzo istotna, ponieważ staje się podstawą do tworzenia formalnych struktur wsparcia. W Polsce orzeczenie o potrzebie kształcenia specjalnego jest niezbędnym warunkiem uzyskania prawa do takich świadczeń jak: dodatkowe zajęcia specjalistyczne, pomoc pedagoga specjalnego w czasie lekcji, prawo do darmowych podręczników, dowozu do szkoły, dostosowanie wymagań egzaminacyjnych do indywidualnych potrzeb itd. ${ }^{20} \mathrm{~W}$ systemie włączającym stosuje się zasadę maksymalnej normalizacji środowiska szkolnego odzwierciedloną w teorii Wolfa Wolfenbergera. Wysunął on tezę o potrzebie maksymalnego wykorzystywania zasobów jednostki i środowiska przy jednoczesnym ograniczaniu do minimum specjalistycznej pomocy, która mogłaby prowadzić do naznaczenia osoby i nadania jej „sspecjalnego" statusu ${ }^{21}$. Uznanie priorytetowego znaczenia tej zasady w organizacji procesu kształcenia uczniów o specjalnych potrzebach ma za zadanie wyeliminowanie wszystkich zbędnych elementów, które niepotrzebnie zwracałyby uwagę na określone deficyty i utwierdzałyby kogokolwiek w przekonaniu o inności obarczonego nimi ucznia. Chroni go to w pewnym stopniu przed negatywnymi społecznymi skutkami niepełnosprawności.

Uczniowie w systemie integracyjnym są dobierani do klas w sposób celowy, przede wszystkim ze względu na rodzaj zaburzenia. Fakt posiadania orzeczenia o potrzebie kształcenia specjalnego przez przynajmniej troje uczniów jest podstawą do utworzenia klasy integracyjnej. Klasa taka jest mniej liczna niż zwykła i jest do niej przypisany dodatkowy pedagog specjalny, którego zadaniem jest wspieranie realizacji zaleceń z orzeczeń uczniów z niepełnoprawnością. Z punktu widzenia organizacji nauczania uczniowie ci są najważniejszym ogniwem całego procesu, ponieważ stanowią "trzon" klasy, a ich obecność determinuje większość działań podejmowanych w przestrzeni integracyjnej. Reszta uczniów stanowi "tto" dla procesów edukacji i rehabilitacji osób z orzeczeniem ${ }^{22}$. System włączający nie określa minimalnej liczby członków zespołu klasowego posiadających diagnozę niepełnosprawności. Dzięki temu każde dziecko ma szansę na otrzymywanie wysokiej jakości edukacji w swojej szkole rejonowej, bez konieczności naznaczania go etykieta, która jest nierozerwalnie związana z posiadaniem orzeczenia o potrzebie kształcenia specjalnego uprawniającego do otrzymania pomocy, którajest de facto warunkiem jego efektywnego funkcjonowania. Każdy uczeń w klasie ma prawo do osiagania maksimum swoich możliwości w ramach ogólnodostępnej edukacji.

Omawiane systemy różnią się pod względem podstawowych wartości wyznaczających cele i sposób pracy szkoły. W przypadku szkoły integracyjnej zaspokajanie potrzeb uczniów o specjalnych potrzebach edukacyjnych jest jednym

18 Rozporządzenie Ministra Edukacji Narodowej z dnia 30 kwietnia 2013 r., dz. cyt.

19 Education Act, http://www.legislation.gov.uk/ukpga/1996/56/section/312, 13.11.2014.

20 D. Apanel, Teoria i praktyka ksztalcenia integracyjnego..., dz. cyt., s.229

21 G. Szumski, Integracyjne ksztalcenie... dz. cyt., s. 140.

22 Z. Gajdzica, Kategorie sukcesów w opiniach nauczycieli klas integracyjnych jako przyczynek do tworzenia koncepcji edukacji integracyjnej, Kraków-Katowice 2013, s. 197. 
z podstawowych zadań. Określają je główne kierunki realizacji polityki oświatowej państwa, formułowane wraz w początkiem każdego nowego roku szkolnego. W Polsce w latach 2013/2014 oraz 2014/2015 do najważniejszych celów zaliczone zostało kształcenie uczniów niepełnosprawnych w szkołach ogólnodostępnych. Odnosząc się do teorii Zenona Gajdzicy ${ }^{23}$, twórcy dwóch koncepcji edukacji integracyjnej, można zauważyć, że tak umotywowane postępowanie podporządkowane jest tzw. integracji rehabilitacyjnej. Oparta jest ona na medycznym paradygmacie niepełnosprawności, uprzedmiotawiającym jednostki odbiegające od normy rozwojowej. Podejście to zdominowane jest przez kulturę rehabilitacyjna, której przejawem jest skupienie się na leczeniu zaburzeń i wyrównywaniu braków. Przeciwieństwem opisanej koncepcji jest integracja uspołeczniająca, bliższa założeniom edukacji włączającej. W tym przypadku jako najważniejzze zadanie szkoły wskazuje się edukację i socjalizację oraz budowanie pozytywnych relacji społecznych wśród uczniów. Rehabilitacja jest jednym z wielu celów pracy placówki, realizowanym równolegle z innymi, nie wysuwającym się jednak na czoło listy priorytetów. Bardzo często działania wyrównawcze i korekcyjne podejmowane są poza szkoła, w ramach zajęć pozalekcyjnych.

W systemie integracyjnym występuje znacząca instytucjonalizacja potrzeb osób z niepełnosprawnościa, na co wskazuje między innymi przytoczony wcześniej przykład nabywania prawa do specjalistycznego wsparcia psychologiczno-pedagogicznego. Z definicji edukacji włączającej wynika, że szkoła powinna starać się sprostać potrzebom każdego ucznia, bez konieczności uruchamiania formalnych procedur, polegając głównie na posiadanych zasobach. Tak rozumiana samowystarczalność szkoły jest niewątpliwie bardzo kosztowna. W przypadku ujawnienia przez ucznia specjalnych potrzeb edukacyjnych konieczna jest możliwość uruchomienia dodatkowych nakładów finansowych i kadrowych. Taka elastyczność nie jest realna bez daleko posuniętej decentralizacji systemu finansowania oświaty. Egzemplifikacją opisanego rozwiązania jest system duński. W kraju tym pieniądze przekazywane są gminom w zryczałtowanej kwocie obliczanej na podstawie zamieszkującej ją liczby ludności, a następnie przekazywane do szkót. O sposobie ich rozdysponowania decydują dyrektorzy w porozumieniu z rodzicami i lokalnymi centrami pomocy psychologiczno-pedagogicznej, które na bieżąco monitorują potrzeby uczęszczających do szkół uczniów. Lokalne władze, najlepiej znając specyfikę danej społeczności, same decydują o tym, gdzie ulokować otrzymywane z budżetu państwa środki finansowe ${ }^{24}$.

Ostatnim omawianym w niniejszym opracowaniu aspektem odróżniającym system edukacji integracyjnej od włączającej jest rola pedagoga specjalnego we wspomaganiu uczniów ze specjalnymi potrzebami edukacyjnymi oraz jego relacje z nauczycielem przedmiotowym, nazywanym również „wiodącym”. W integracji pedagog specjalny ma przede wszystkim wspierać edukację uczniów z orzeczeniem o potrzebie kształcenia specjalnego. Czyni go to jednym z elementów instytucjonalizacji procesu wspomagania. Sytuacja ta sprzyja ponadto „Zrzucaniu” odpowiedzialności za powodzenie edukacji omawianej grupy na pedagogów specjalnych jako „specjalistów od niepełnosprawności”. Perspektywa włączająca każe przedefiniować rolę pedagoga i przełożyć główną odpowiedzialność za edukacyjny sukces wszystkich uczniów na nauczyciela wiodącego. Pedagogika specjalna spełnia rolę służebną wobec ogólnej, a zadaniem specjalistów jest wspieranie nauczycieli w efektywnym radzeniu sobie z pojawiającymi się $\mathrm{w}$ ich pracy utrudnieniami. Wsparcie pedagoga specjalnego w formach inkluzywnych „przechodzi w proces wspierania grupowego, zinterioryzowanego przez wszystkich aktorów. Nie jest ono postrzegane jako szczególny element integracji, ale proces należny wszystkim, którzy w danej sytuacji (postrzeganej jako trudna) nie radzą sobie ze zbiorem ogólnych wymagań25"

\section{Podsumowanie}

Pomimo iż system integracyjny w założeniach ma służyć normalizacji i wyrównywaniu szans życiowych osób z niepełnosprawnościa, praktyka pokazuje, że w rzeczywistości legitymizuje wiele działań prowadzących do pogłębiania ich społecznej izolacji. Przedstawiona w artykule analiza polskich rozwiązań z zakresu edukacji integracyjnej eksponuje wyraźnie, że jej fundamentem jest przekonanie o istnieniu dwóch grup - osób pełnosprawnych i posiadających różnego rodzaju odchylenia od normy. Do realizacji podstawowych założeń, na których oparta jest teoria integracji, nie wystarczy umożliwienie osobom z niepełnosprawnością funkcjonowania w społeczeństwie "na pewnych zasadach". Urzeczywistnienie postulatów integracyjnych wymaga pozbycia się wszelkich zapisów legislacyjnych mogących stanowić przesłanki do bu-

23 Tamże, s. 196-210.

24 European Agency for Development in Special Needs Education, Financing of special needs education. A seventeen-country Study of the Relationship between Financing of Special Needs Education and Inclusion, http:/www.european-agency.org/sites/default/files/financing-of-special-needs-education_Financing-EN.pdf, 13.11.2014.

25 Z. Gajdzica, Kategorie sukcesów w opiniach nauczycieli.., dz. cyt., s. 209. 
dowania podziałów pomiędzy ludźmi. Możliwość otrzymania adekwatnej do potrzeb pomocy nie powinna być prawem zarezerwowanym dla określonej grupy osób, uprawnionej do tego ze względu na posiadanie formalnej diagnozy.

Aktualnie zachodzące w Polsce zmiany dają nadzieję, że szkoła publiczna będzie stawała się coraz bardziej dostępna dla wszystkich uczniów, także tych posiadających specjalne potrzeby edukacyjne. Ważne jest jednak, aby właściwie definiować rzeczywistość i nie poprzestawać na tym, co jest, lecz wciąż dążyć do budowania lepszego społeczeństwa stwarzającego każdemu człowiekowi możliwość pełnego, nieskrępowanego rozwoju.

\section{Bibliografia:}

[1] Apanel D., Teoria i praktyka kształcenia integracyjnego w Polsce w latach 1989-2012, Torun 2014.

[2] Czyż A., Idea edukacji włączającej w opinii pedagogów, Kraków, 2013.

[3] Dykcik W., Wprowadzenie w przedmiot pedagogiki specjalnej jako nauki, [w:] Dykcik W. (red.) Pedagogika specjalna, Poznań 2006.

[4] Gajdzica Z., Kategorie sukcesów w opiniach nauczycieli klas integracyjnych jako przyczynek do tworzenia koncepcji edukacji integracyjnej, Kraków-Katowice 2013.

[5] Hulek A., Integracyjny system kształcenia i wychowania, [w:] Hulek A. (red.), Pedagogika rewalidacyjna, Warszawa 1980.

[6] Krauze-Sikorska H., Praca z dziećmi o specjahnych potrzebach edukacyjnych i jej implikacje dla ich rozwoju, [w:] H. Sowińska (red.) Dziecko w szkolnej rzeczywistości. Założony a rzeczywisty obraz edukacji elementarnej, Poznań 2011.

[7] Kugelmass J. W., The inclusive school. Sustaining equity and standards, New York 2004.

[8] Lipińska-Lokś J, Zmiany stosunków między dziémi pełnosprawnymi w dziećmi z niepetnosprawnościa w klasach integracyjnych, Zielona Góra 2011.

[9] Szumski G., Integracyjne kształcenie niepetnosprawnych. Sens i granice zmiany edukacyjnej, Warszawa 2009.

[10] UNESCO, Open file on inclusive education, Support materials for managers and administrators, Paris 2001.

[11] Wendland M., Konstrktywizm komunikacyjny, Poznań 2011.

\section{Netografia:}

[12] European Agency for Development in Special Needs Education, Financing of special needs education. A seventeen-country Study of the Relationship between Financing of Special Needs Education and Inclusion, http://www.european-agency.org/sites/default/files/financing-of-specialneeds-education_Financing-EN.pdf, 25.11.2014.

[13] Kossewska J., Wspótczesne modele integracji szkolnej dzieci niepetnosprawnych, http://libproxy.up.krakow.pl/plikownia/pdf/kossewska_02.pdf , 25.11.2014.

[14] Integracja, w: Słownik Języka Polskiego PWN, http://spp.pwn.pl/sjp/integracja;2561723.html, 25.11.2014.

[15] Inkluzja, w: Słownik Języka Polskiego PWN, http://sjp.pwn.pl/sjp/inkluzja;2466290.html, 25.11.2014.

\section{AKTy PRAWNE/ROZPORZĄDZENIA:}

[16] Education Act, http://www.legislation.gov.uk/ukpga/1996/56/section/312, 13.11.2014.

[17] Konwencja o prawach osób niepełnosprawnych, (Dz.U. z 2012 r., poz. 1169).

[18] Rozporządzenie Ministra Edukacji Narodowej z dnia 30.04.2013 r. w sprawie zasad udzielania i organizacji pomocy psychologiczno-pedagogicznej w publicznych przedszkolach, szkołach i placówkach (Dz.U.z 2013 r., poz.532);

[19] Rozporządzenie Ministra Edukacji Narodowej z dnia 17.11.2010 r. w sprawie warunków organizowania kształcenia, wychowania i opieki dla dzieci i młodzieży niepełnosprawnych oraz niedostosowanych społecznie w specjalnych przedszkolach, szkołach i oddziałach oraz ośrodkach (Dz.U. Nr 228, poz.1489).

[19] Rozporządzenie Ministra Edukacji Narodowej z dnia 17.11.2010 r. w sprawie warunków organizowania kształcenia,wychowania i opieki dla dzieci i młodzieży niepełnosprawnych oraz niedostosowanych społecznie w przedszkolach, szkołach i oddziałach ogólnodostępnych lub integracyjnych wraz z późniejszymi zmianami (Dz. U. Nr 228, poz.1490; Dz.U. z 2012 r., poz. 982 i Dz.U. z 2013 r., poz. 957). 